\title{
Communicatie in de gezondheidszorg: mensenwerk met onderbouwing
}

Het TMO dat voor u ligt lijkt wel een themanummer. De vier wetenschappelijke artikelen in dit nummer hebben op de een of andere manier te maken met communicatie.

Gerritsen en Nauta behandelen de (interdisciplinaire) samenwerking in de gezondheidszorg. Ze bespreken wat er allemaal komt kijken bij deze samenwerking. De verschillende aspecten van samenwerking worden ingebed in de relevante theoretische kaders. De auteurs geven tenslotte richtlijnen voor het leren en overdragen van samenwerk-vaardigheden gedurende de medische opleiding.

De Natris en Brouwers hebben onderzocht of ziekenhuispersoneel meer geneigd is aan een communicatietraining mee te doen nadat ze een longitudinale basiscursus hebben gevolgd. Dat blijkt niet zo eenvoudig te liggen. De bereidheid aan een volgende training mee te doen is verschillend voor mensen uit verschillende afdelingen. Ook dit artikel wordt afgerond met het beschrijven van factoren die deelname aan vervolgcursussen wel systematisch lijken te beïnvloeden.

Bakker et al. onderzochten of er onder specialisten in Noord- en Oost-Nederland wel draagvlak is voor de grootscheepse herziening van de medische vervolgopleidingen. Dat blijkt er zeker te zijn. Met name worden veranderingen voorspeld en gewenst op (alweer) het gebied van interdisciplinaire samenwerking.

Cals et al. beschrijven het positieve effect van een contextgebonden training in communicatievaardigheden voor huisartsen. Dit artikel is het resultaat van samenwer- king tussen onderzoekers van vier instituten uit twee landen. De auteurs geven hiermee impliciet aan zelf goed in staat te zijn tot interdisciplinaire en internationale samenwerking! Het artikel is eerder verschenen in Patient Education and Counseling, maar de redactie van het TMO vond het voldoende van belang voor de Nederlandstalige lezers om het ook in het Nederlands te publiceren.

Uit deze opsomming blijkt dat communicatie in brede zin, en interdisciplinaire samenwerking in de gezondheidszorg sterk in de belangstelling staan. Niemand zal het belang ontkennen. De toegenomen aandacht voor communicatie in de gezondheidszorg herbergt echter ook een risico. We communiceren immers allemaal al ons hele leven. Communicatie lijkt voor een groot deel op 'common sense' te berusten, de richtlijnen liggen nogal eens erg voor de hand. Maar zijn die richtlijnen eigenlijk wel goed onderbouwd? Of varen we misschien iets teveel op onze 'common sense', zonder dat we het naadje van de kous weten? Weten we eigenlijk wel echt welke communicatievaardigheden nodig zijn in welke situatie? Weten we eigenlijk wel of onderwijs in deze vaardigheden echt effect heeft? Weten we wel hoe we deze vaardigheden het beste kunnen trainen? Weten we eigenlijk wel of aangetoond effect op een toets ook betekent dat er effect te zien is in de praktijk?

De antwoorden op deze vragen zijn allerminst eenduidig. Ik verdien zo'n 30 jaar mijn brood met onderwijs in en onderzoek naar communicatie tussen artsen en 
patiënten, en ben aardig op de hoogte van de literatuur op dat gebied. De meeste vaardigheden blijken wel te werken in de praktijk. Maar zelfs op dit welomschreven gebied zijn er veel onduidelijkheden. De meeste vaardigheden die we nu onderwijzen zijn zo'n 30 jaar geleden beschreven en de maatschappij is aanzienlijk veranderd sinds die tijd: verschuiving van de care-cure balans, heterogenere samenleving, beschikbaarheid van veel meer informatie, etc.

Het is alleen al om deze redenen dat we weer trots zijn op dit nummer van het TMO. We publiceren pogingen om tipjes van deze sluiers op te heffen. Wetenschappelijk onderzoek kan iets meer klaarheid brengen in vragen naar de waarde van onze onderwijskundige interventies en het is duidelijk dat er nog veel onderzoek nodig is. Daarnaast moeten we niet vergeten dat onderwijs, samenwerking en communicatie mensenwerk is. De spelers in ons vak zijn eigenwijze, idiosyncratische, emotionele partners, die het hoofdzakelijk moeten hebben van hun bezieling en bevlogenheid. Vandaar dat we gelukkig ook in dit nummer, door middel van de bijdrage van Schretlen: 'Kunst, literatuur en dokters zonder een goed glas wijn', de wetenschappelijke benadering van problemen in balans kunnen brengen met aandacht voor de menselijke subjectiviteit. De redactie wenst $\mathrm{u}$ veel lering bij de lezing van dit nummer van het TMO.

Jan van Dalen 